\title{
UNIVERSITY GRANTS IN GREAT BRITAIN
}

\begin{abstract}
HE annual returns from universities and colleges in receipt of Treasury grants from the academic year 1957-58, now covering twenty-one universities and three colleges, issued by the University Grants Committee, records a further increase in the number of full-time students to 95,442 , compared with 89,866 in 1956-57 (Pp. 54. Cmnd. 832. London: H.M. Stationery Office, 1959. 5s. net). Statisties collected in October 1958 showed a university population of about 100,000 , and this number is expected to reach at least 110,000 by $1961-62$. There were 6,180 fulltime and 2,208 part-time students from overseas within the British Commonwealth and 3,982 full-time and 1,904 part-time students from foreign countries; for $1956-57$ the corresponding figures were 6,115 and 2,016 for the Commonwealth and 3,792 and 1,756 for foreign countries. Of full-time new students $36 \cdot 4$ per cent were in arts, 23.7 per cent in pure science, $19 \cdot 0$ per cent in technology and 13.7 per cent in medicine : these figures compare with $38 \cdot 7,15 \cdot 2,13 \cdot 5$ and $26 \cdot 1$, respectively, in 1938-39. For full-time women students the corresponding figures for $1957-58$ are $63 \cdot 5,20 \cdot 0,0 \cdot 8$ and $12 \cdot 1$, respectively, and for 1938-39, 64.7, 15.9, $0 \cdot 8$ and $16 \cdot 2$. Fulltime advanced students of pure science numbered 3,853 ( 34.8 per cent); of technology, $1,916(17 \cdot 3$ per cent) ; and of medicine, 968 (8.8 per cent); 3,007 students were taking postgraduate courses in teacher training.

Of the full-time students 76,687 were reading for a first degree, 3,937 for a first diploma and 14,069 engaged in research or other advanced work, the corresponding figures for $1956-57$ being $71,713,3,969$ and 13,379, respectively. Of the now full-time students, $24 \cdot 0$ per cent were in pure science, $15 \cdot 4$ per cent in technology and $9 \cdot 3$ per cent in medicine;
\end{abstract}

for 1956-57 the corresponding figures were $23 \cdot 8,15 \cdot 0$ and $9 \cdot 6$ per cent, respectively.

The proportion of assisted students was $79 \cdot 2$ per cent compared with $75 \cdot 7$ per cent in $1956-57$ and 71.9 per cent in 1953-54, ranging from 92.2 per cent in Wales, 86.7 per cent in English universities, excluding Oxford, Cambridge and London, to 67.2 per cent for Scotland. Full-time teaching and researeh staff increased to 10,542 , compared with 10,485 in 1956-57. The proportion of full-time students residing in colleges or halls of residence was 26.4 per cent compared with $27 \cdot 4$ per cent in 1956-57 although the total, 25, 174, was higher. 'The proportion of men in residence, excluding Oxford, Cambridge and London, was $22 \cdot 4$ per cent and of women, $38 \cdot 6$ per cent, whereas 46,237 (48.4 per cent) were in lodgings and 24,031 $(25 \cdot 2$ per cent) at home, compared with 46 per cent and $26 \cdot 6$ per cent, respectively, the previous year.

Of the recurrent income of $£ 49,418,302$ (an increase of $£ 7,762,693$ on $1956-57$ ) $£ 34,953,406$ was from Parliamentary grants $(70 \cdot 7$ per cent). Income from fees increased from $11 \cdot 2$ per cent to $11 \cdot 5$ per cent, local authority grants decreased from $3 \cdot 1$ to $2 \cdot 8$ per cent, endowments from $4 \cdot 0$ per cent to $3 \cdot 6$ per cent, donations and subscriptions from $1 \cdot 2$ to $1 \cdot 1$ per cent, and payments for research $(£ 3,008,898)$ from $6 \cdot 5$ per cent to $6 \cdot 1$ per cent. Non-recurrent grants in respect of eapital expenditure amounted to $£ 11,816,479$ compared with $£ 9,134,185$ in $1956-57$ and of the recurrent expenditure of $£ 48,335,053-$ an increase of $£ 6,825,350$ on $1956-57-7 \cdot 1$ per cent was spent on administration, $68 \cdot 6$ per cent on departmental maintenance and $12 \cdot 5$ per cent on maintenance of premises. Expenditure on libraries increased from $£ 1,620,958$ to $£ 1,821,943$ but decreased to $3 \cdot 8$ per cent of the total.

\section{NUCLEAR RESEARCH IN AUSTRALIA}

N the sixth annual report of the Australian Atomic Energy Commission (Commonwealth of Australia, 1958. Pp. 62. Sydney: Australian Atomic Energy Commission, 1959), covering the year ended June 30,1958 , considerable space is devoted to the Commission's Research Establishment at Lucas Heights, which was officially opened by the Prime Minister of Australia, the Rt. Hon. R. G. Menzies, on April 18, 1958. During the period up to the beginning of May approximately 4,500 visitors went to the Establishment. Many of the major buildings have been completed and this has enabled the research staff to return from Harwell and to begin to design and assemble equipment for their research projects. The Commonwealth Government has approved a further building programme involving an expenditure of $£ 1 \cdot 6$ million during $1958-59$ and $1959-60$ on new laboratories and services, including engineering research laboratories, a building in which the fabrication and chemistry of beryllium fuels can be studied, and post-irradiation handling equipment.

The report details the work of the principal sections of the Establishment and the various research projects to be undertaken. The main function of the
Isotopes Section is the advisory service to industry and research, and 310 requests for advice on various aspects of isotope production were dealt with during the year. Australian industry and research in comparison with the United States of America or the United Kingdom has, however, been slow to accept the use of radioisotopes. The Section assisted in a large-scale field test, in which a radioisotope technique was used to measure the efficiency of mixing in a cooling pond in an electrical power station. Other investigations included the development of a method for the continuous investigation of moisture content of brown coal; a technique for tracing sewage sludge in sea disposal ; siltation in the Hunter River ; and the use of radioisotope tracers in cloud physics.

A large proportion of the work of the Technical Physics Section has been concerned with the installation and commissioning of the control gear and instrumentation of the High-Flux Australian Reactor, at the Establishment. Other equipment constructed and tested include a fast scaler, using transistors, with 'plug-in' scales of ten, and a discriminator with resolving time of 1 usec.; a beta-gamma coinci- 